\title{
Integrated 3D modeling of Quaternary sediments in the Beijing Plain, based on a sequential indicator simulation
}

\author{
Al Xiao ${ }^{1}$, Sun Baitao ${ }^{2}$ and Chen Xiangzhao ${ }^{1}$ \\ ${ }^{1}$ Institute of Engineering Mechanics, China Earthquake Administration, Key Laboratory of Earthquake Engineering and Engineering Vibration, China Earthquake \\ Administration; (axz.1988@163.com) \\ 2 Institute of Engineering Mechanics, China Earthquake Administration, Key Laboratory of Earthquake Engineering and Engineering Vibration, China Earthquake \\ Administration; (corresponding author: sunbt@iem.cn)
}

doi: $10.4154 / g c .2019 .28$

\section{Article history:}

Manuscript received April 23, 2019

Revised manuscript accepted September 06, 2019 Available online December 20, 2019

\begin{abstract}
The study of Quaternary sediments has long been a focus for geologists, primarily because they are closely aligned with urban safety assessment, energy exploitation and sustainable development. The Beijing Plain was selected for this study. Using existing drilling data and knowledge of the sedimentary characteristics in this study area, a geological model was developed with Petrel software using the sequential indicator simulation algorithm. The main aims were firstly, to integrate ArcGIS and Petrel with drilling information, a digital elevation model, a stratum sedimentary thickness plan and other multi-platform data on the same platform. Secondly, establish a lithology variogram model and then construct a quaternary lithology model based on the variogram model and finally, use the established lithology model to preliminarily analyze the lateral and vertical distribution rules of Quaternary lithology in the study area. These results provide new methods for the establishment of geologic modeling during the preliminary stages when studying engineering geology. The results will also provide baseline information for later research.
\end{abstract}

Keywords: ArcGIS, Petrel, Sequential indicator simulation, Quaternary, 3D geological modeling
With the maturity of the commercial software for three-dimensional modeling, sequential instruction simulation technology is a new modeling technology which can solve the above problems. This technology can not only reproduce the underground geological properties, but also contextualize the known well data (WANG, 2017; ZHOU, 2017; YUAN et al., 2017; LIU \& ZHOU, 2018). It can also obtain multiple three-dimensional models with equal probability to satisfy the description and analysis of underground uncertainty. At present, the mainstream geological modeling software represented by the Petrel software has been widely used in modeling work during the early stages of exploration (WANG et al., 2014; LI \& WEI, 2015; SONG et al., 2016). In this study, sequential instruction simulation technology will conduct three-dimensional modeling of Quaternary systems in the Beijing Plain. This study aims to provide new thinking and methods for geological modeling in the early stages of urban safety assessments, and to provide theoretical support and baseline information for future urban geological research in Beijing.

\section{GEOLOGICAL SETTING}

Beijing geotectonics are located in the western part of the Yanshan subsidence zone, which is the central part of the North China Platform. During its long geological history, Beijing has experienced a great subsidence and violent orogeny. The tectonic activity was dominated by the Yanshanian movement in the Mesozoic which finally laid the foundation framework of the geological structure and the embryonic geomorphological development in Beijing (HUO, 1989). When combined with the influence of the Himalayan movements since the Cretaceous, the geological history and geomorphological types of Beijing have become more complex and diverse. Until the middle and late Quaternary, Beijing's landforms were being shaped. Beijing is a city with high mountains in the northwest and low plains in the southeast. Sediments are mostly transported from the mountainous areas to the plains $(\mathrm{Bu}-$ research on urban disaster prevention and mitigation. 


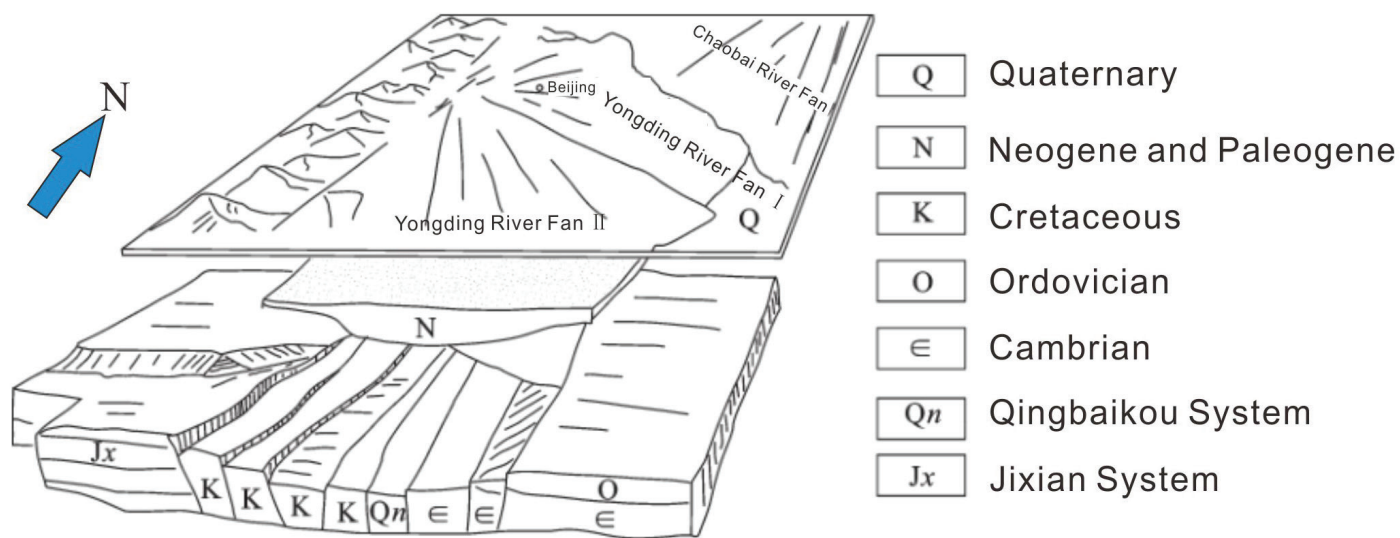

Figure 1. Sketch map of geological structures in Beijing plain (modified from CAl et al., 2016).

reau of Geology and Mineral Resources of Beijing Municipality, 1991). The Quaternary system in the Beijing Plain is generally composed of several huge river fans and depressions. The bedrock burial depth in the Beijing Plain varies greatly and is cut by several faults, forming the famous Beijing Fault Basin (Fig. 1).

Here, the study area is located in the middle and lower areas of Beijing (Fig. 2), comprising a total area of approximately 5600 $\mathrm{km}^{2}$. This includes the main urban area of Beijing and the northern Changping District, the Shunyi District and the Tongzhou District. It also incorporates some areas around the main urban area of Beijing, such as the Yanqing, Miyun, Fangshan Districts and so on.

This geological modeling study focuses on samples from 832 drill holes provided by the Beijing Earthquake Agency. The drilling locations cover the entire study area, with the distribution concentrated in the urban area of Beijing (within the fourth ring). There is a small number outside the urban area (Fig. 3).

\section{TECHNICAL ROUTES}

The key components of this modeling study consist of three sections: 1) processing and loading the drilling data, 2) constructing the model's framework and 3) conducting the geological modeling (Fig. 4). We divided the construction of the model's framework into three steps: 1) the establishment of the model's top and base, 2) the model's quality control and 3) the construction of its horizontal and vertical grid. In order to show the real landscape of the study area, the modeling process of its top and base was different to a traditional software workflow. After building the framework, we completed the geological modeling of the study area by setting reasonable parameters for the sequential indicator simulation.

\section{SEQUENTIAL INDICATOR SIMULATION}

\subsection{Variogram}

A variogram is the core concept in geostatistics. Its accuracy is directly related to the accuracy of the sequential indicator simulation results. In view of this, we firstly introduce the concept of the variogram before explaining the principle of sequential indicator simulation.

The variogram is a method used to describe the space variation of the underground geological property, and the spatial cor-

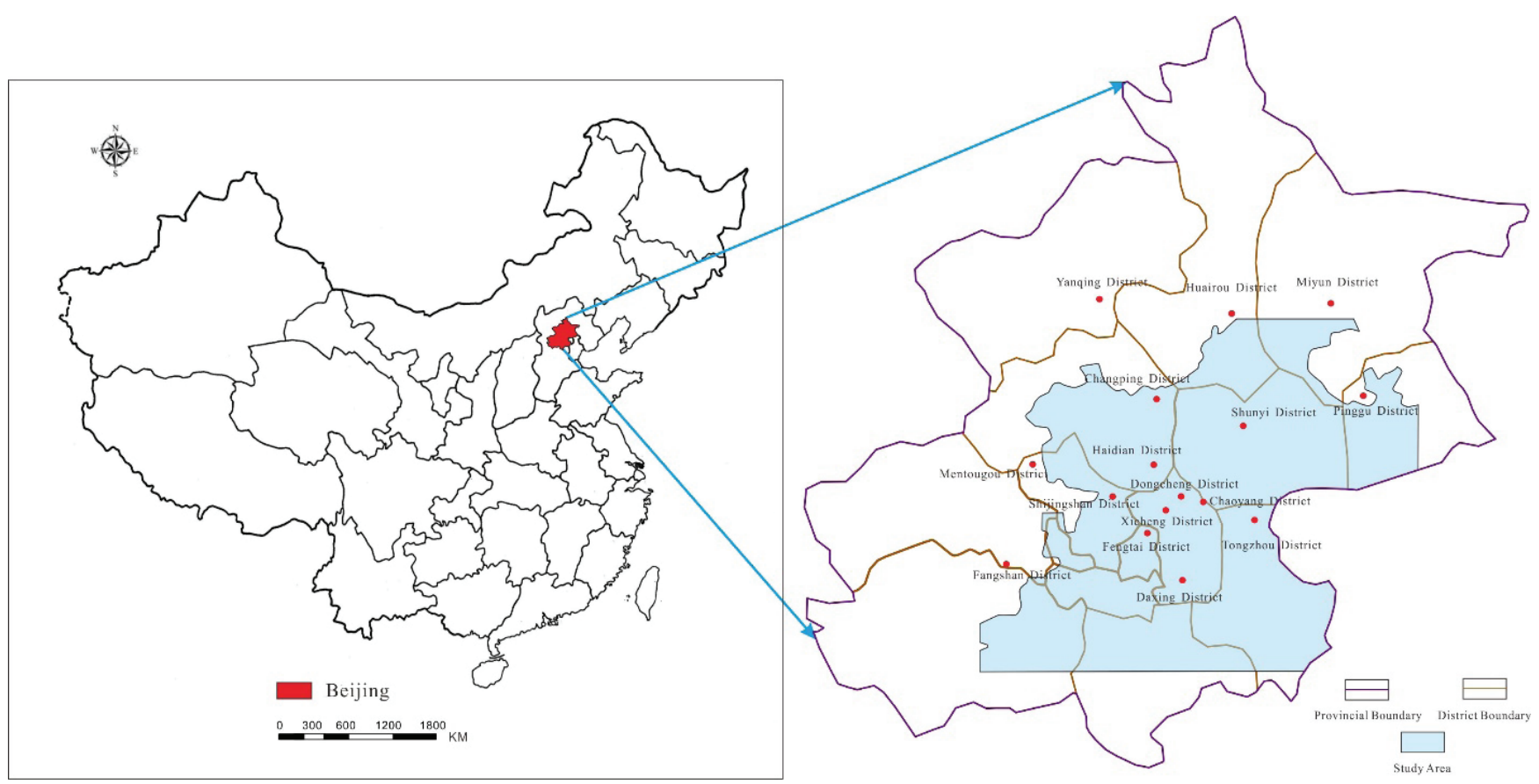

Figure 2. Location of the study area. 

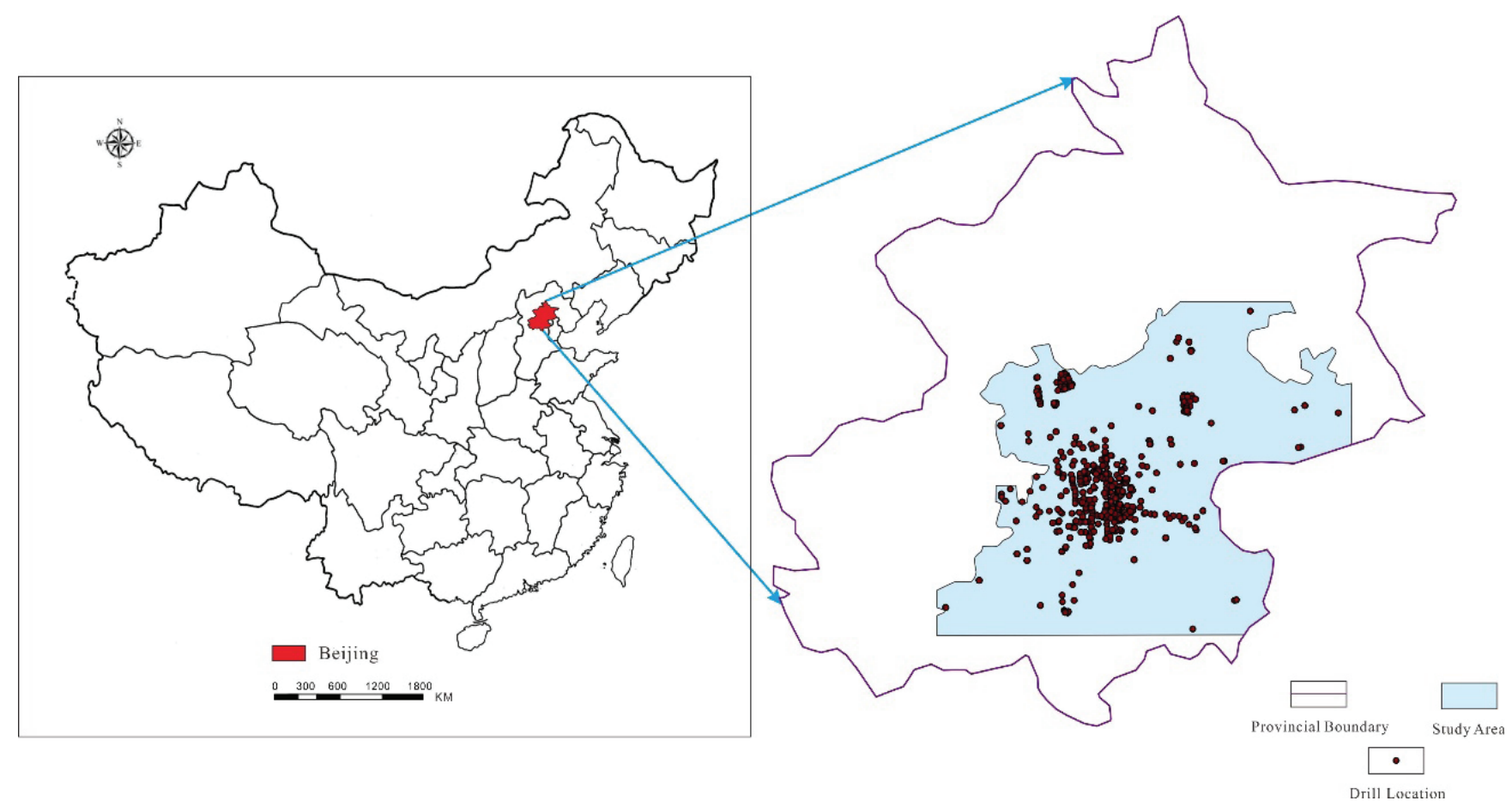

Figure 3. Drilling locations in the study area.

relation of regionalized variables can be described quantitatively (CLAYTON \& ANDRE, 1998). Its principle is that the correlation between close samples in space is strong, while the correlation between distant samples is weak. When the distance between samples exceeds a minimum correlation (range), the influence of distance is small (Fig. 5).

Petrel provides three variogram models, which are Exponential, Spherical and Gaussian (Fig. 6). In practice, not all combinations of the variogram are as typical as the theoretical models.

Figure 6. demonstrates that among the three kinds of theoretical models, the exponential model shows the most significant change in data correlation within the range, the Gauss model shows the least change in data correlation, and the spherical model

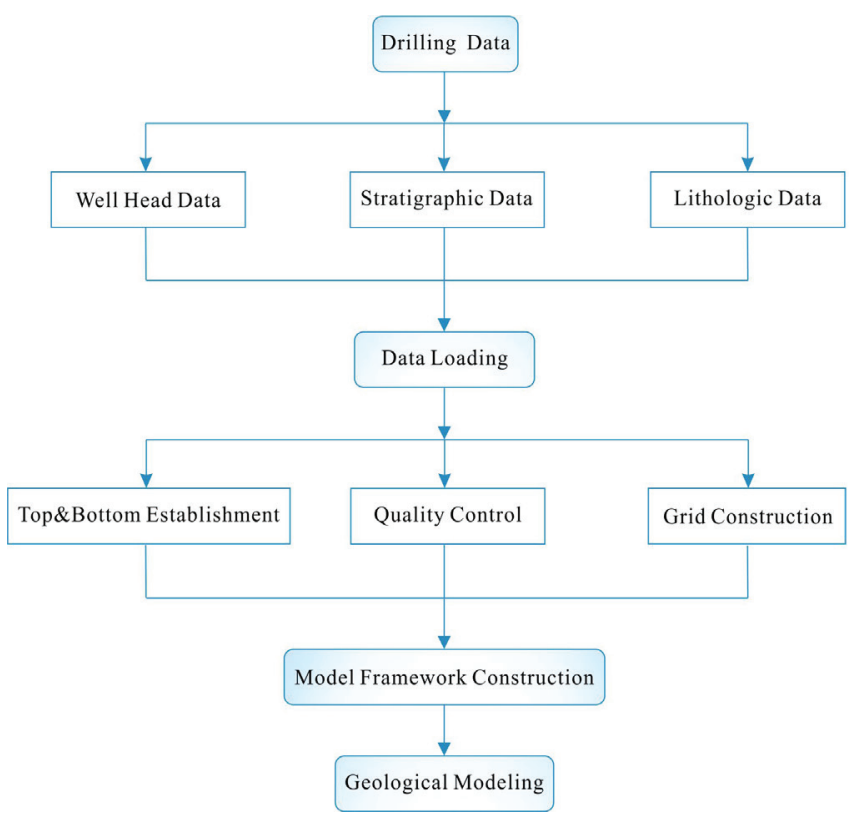

Figure 4. The conceptual framework for the modeling process. shows a moderate change in data correlation. Due to the anisotropy of geological bodies, the variogram calculations must be from three different directions, the main direction, the secondary

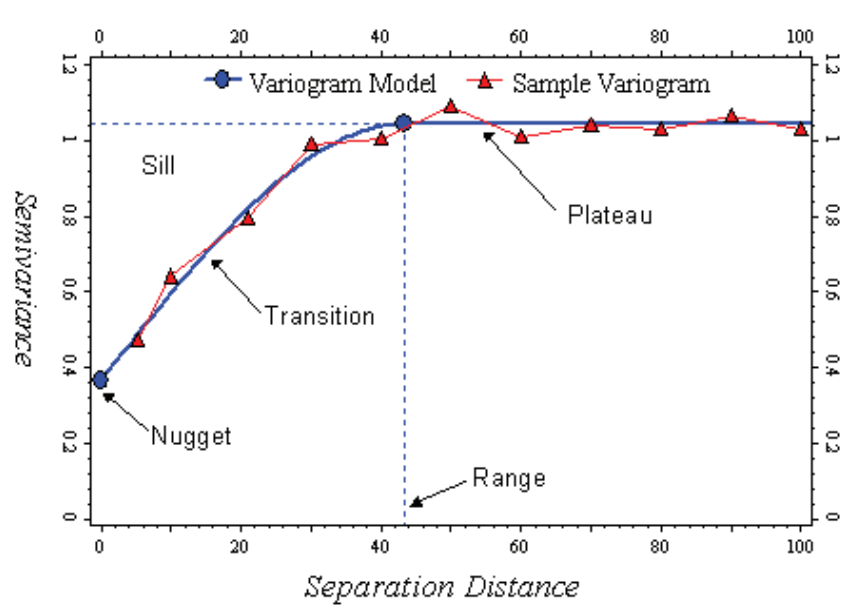

Figure 5. A classic variogram model.

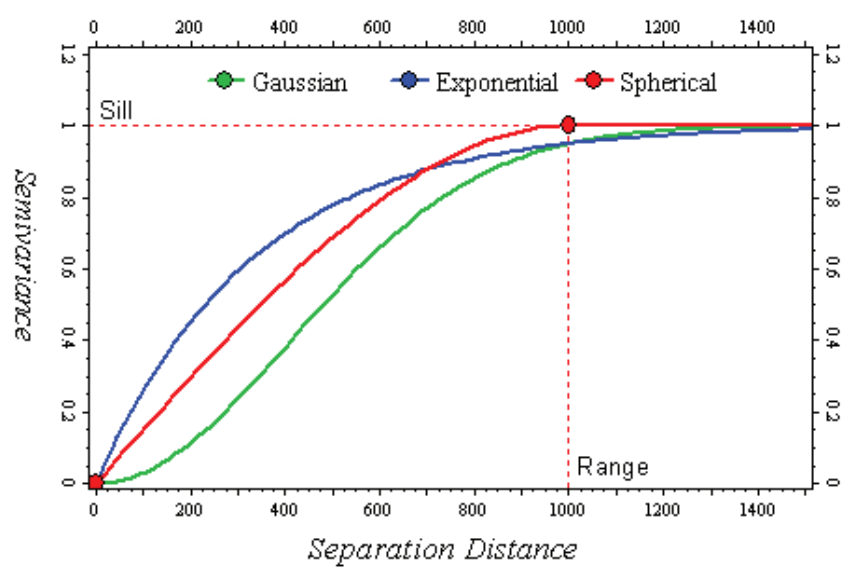

Figure 6. Three types of variogram models. 


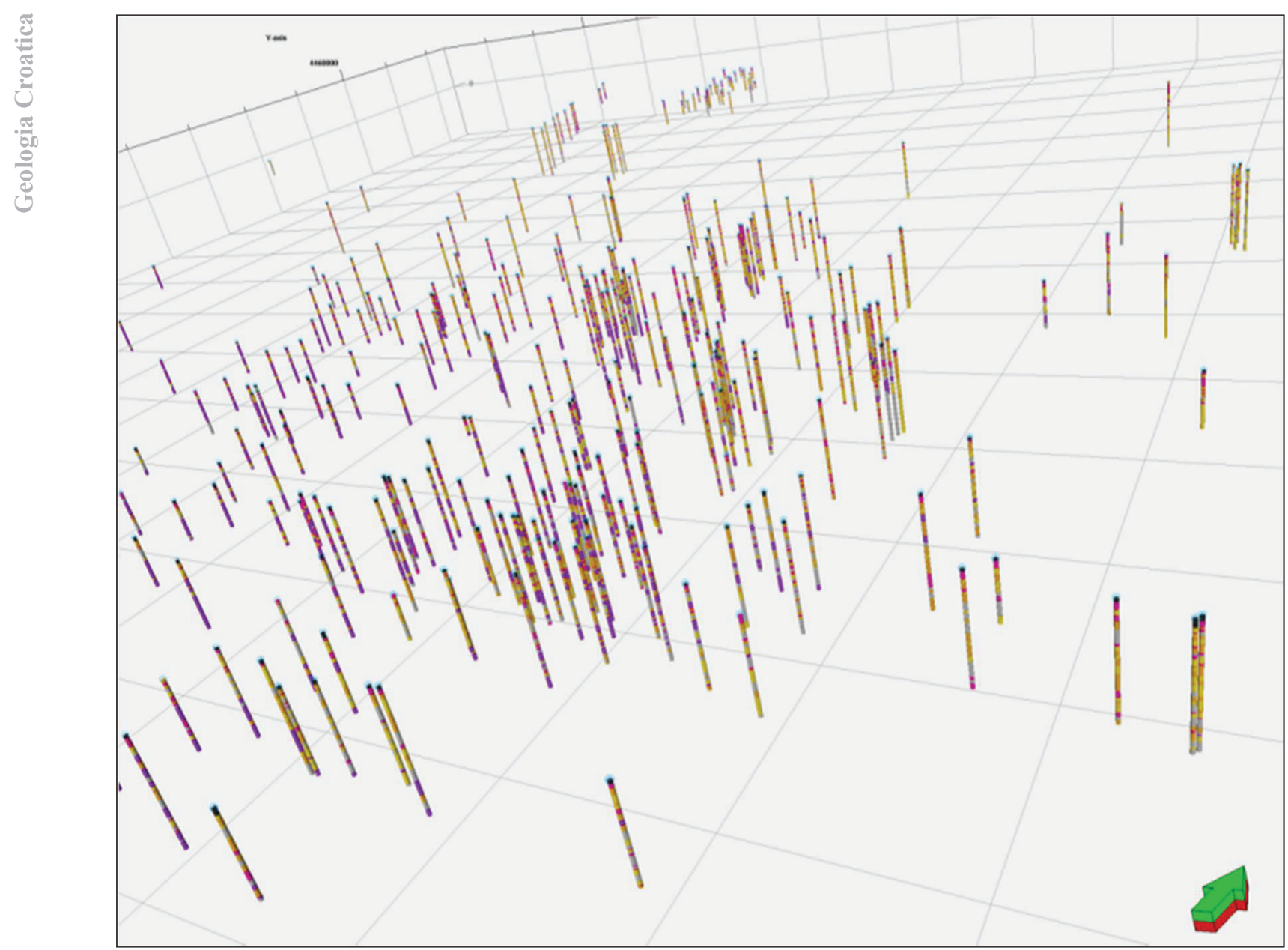

Figure 7.3D visualization of the drill holes in the study area.

direction and the vertical direction. The main direction represents the maximum correlation between data points in this direction, the secondary direction is the direction perpendicular to the main direction and the vertical direction is the direction perpendicular to the plane formed by both the main and the secondary directions.

\subsection{The principle of sequential indicator simulation and its implementation}

The principle of sequential indicator simulation can be explained as follows (FENG et al., 2001):

Assume that $\{\mathrm{Z}(\mathrm{x}), \mathrm{x} \in \mathrm{A}\}$ is a random function corresponding to regional variables, wherein A represents a region. For a threshold $\mathrm{z}_{0}$ of regionalized variables, a two-dimensional indicator random variable $\mathrm{I}\left(\mathrm{x} ; \mathrm{z}_{0}\right)$ is defined as:

$$
I\left(x ; z_{0}\right)= \begin{cases}1 & Z(x) \leq z_{0} \\ 0 & Z(x)>z_{0}\end{cases}
$$

If the random function $Z(x)$ has a set of observations $\{Z(x \alpha)$, $\alpha \in(\mathrm{n})\}$, then the conditional probability distribution of $Z(\mathrm{x})$ based on the set of observations is equal to the conditional expectation of I $\left(\mathrm{x} ; \mathrm{z}_{0}\right)$ :

$$
\mathrm{E}\left\{\mathrm{I}\left(\mathrm{x} ; \mathrm{z}_{0}\right) \mid \mathrm{z}\left(\mathrm{x}_{\alpha}\right) \alpha \in(\mathrm{n})\right\}=\mathrm{p}\left\{\mathrm{Z}(\mathrm{x}) \leq \mathrm{z}_{0} \mid \mathrm{z}\left(\mathrm{x}_{\alpha}\right), \alpha \in(\mathrm{n})\right\}
$$

Then the conditional probability $\mathrm{p}\left\{\mathrm{Z}(\mathrm{x}) \mathrm{z}_{0} \mathrm{I}\left(\mathrm{x} ; \mathrm{z}_{0}\right) \mid \mathrm{z}\left(\mathrm{x}_{\alpha}\right), \alpha \in(\mathrm{n})\right\}$ can be estimated by the estimates of the indicative conditional expectations $\left.\mathrm{E}\left\{\mathrm{I} ; \mathrm{x}_{0}\right) \mid \mathrm{z}\left(\mathrm{x}_{\alpha}\right), \alpha \in(\mathrm{n})\right\}$.
According to the Kriging method, the Kriging estimate is the conditional cumulative probability of the point, which is expressed as follows:

$$
\begin{gathered}
\mathrm{F}\left(\mathrm{x} ; \mathrm{z}_{0} \mid \mathrm{z}\left(\mathrm{x}_{\alpha}\right), \alpha \in(\mathrm{n})=\mathrm{p}\left\{\mathrm{Z}(\mathrm{x}) \leq \mathrm{z}_{0} \mid \mathrm{z}\left(\mathrm{x}_{\alpha}\right),\right.\right. \\
\alpha \in(\mathrm{n})\}=\sum_{\alpha=1}^{\mathrm{n}} \lambda_{\alpha}\left(\mathrm{x} ; \mathrm{z}_{0}\right) \mathrm{I}\left(\mathrm{x}_{\alpha} ; \mathrm{z}_{0}\right)
\end{gathered}
$$

Among these, $\mathrm{I}(\mathrm{x} \alpha ; \mathrm{z} 0)$ represents the indicative value of the sample point at the threshold $z 0$, and $\lambda \alpha(x ; z 0)$ represents the corresponding indicator Kriging weight, which is determined by the following Kriging equations:

$$
\left\{\begin{array}{c}
\sum_{\beta=1}^{\mathrm{n}} \lambda \beta\left(\mathrm{x} ; \mathrm{z}_{0}\right) \mathrm{C}_{\mathrm{I}}\left(\mathrm{x}_{\beta}-\mathrm{x}_{\alpha} ; \mathrm{z}_{0}\right)+\mu\left(\mathrm{x} ; \mathrm{z}_{0}\right)=\mathrm{C}_{\mathrm{I}}\left(\mathrm{x}-\mathrm{x}_{\alpha} ; \mathrm{z}_{0}\right) \alpha=1,2,3, \ldots, n \\
\sum_{\beta=1}^{\mathrm{n}} \lambda \beta\left(\mathrm{x} ; \mathrm{z}_{0}\right)=1
\end{array}\right.
$$

In the formula, $\mathrm{CI}(\mathrm{x} ; \mathrm{z} 0)$ is a covariance function. It can be seen that $\mathrm{CI}(\mathrm{x} \beta-\mathrm{x} \alpha ; \mathrm{z} 0)$ represents the covariance function between all known points, and $\mathrm{CI}(\mathrm{x}-\mathrm{x} \alpha ; \mathrm{z} 0)$ represents the covariance function between the selected unknown points and all known points, while $(x ; z 0)$ is a Lagrange multiplier. This means that $\mathrm{K}$ thresholds need such Kriging equations, and the covariance function of each Kriging equation is different, so the actual calculation process is very complex.

In summary, under given $\mathrm{K}$ thresholds, each threshold corresponds to a Kriging equation for any point to be evaluated. The 
corresponding probabilities under each threshold can be obtained by solving the equations. Then all the probabilities belonging to each threshold are normalized to determine the conditional distribution probability function at the point to be estimated and a concrete implementation of the point to be estimated can be obtained.

When the random variable $\mathrm{Z}(\mathrm{x})$ is a discrete variable (such as sedimentary facies), the formula is simpler. The number of $\mathrm{K}$ thresholds corresponds to the $\mathrm{K}$ type of the random variable $\mathrm{Z}$ (x). Assuming that there are three lithologies in the study area and their corresponding numbers are 1,2 and 3, the corresponding threshold is the number of these three lithologies. It can change the formula of the indicator variable to the following formula:

$$
I\left(x ; z_{0}\right)=\left\{\begin{array}{l}
1 Z(x) \in \text { type } \mathrm{K} \\
0 \text { else }
\end{array}\right.
$$

In summary, the implementation steps of sequential instruction simulation are as follows:
(1) Divide variables into K thresholds.

(2) Calculate the variation function of each indicator variable.

(3) Simulate the estimated point.

a. Define conditional data within the search scope.

b. For any $\mathrm{k}=1,2, \ldots, \mathrm{K}$, which represents the corresponding threshold, establish the ordinary kriging equations based on the indicator covariance model of the threshold. Then solve the Kriging equations and calculate the probability that the sample points belong to the corresponding threshold.

c. Normalize all the probability belonging to each threshold, and then determine the conditional distribution probability function at the point to be evaluated and its concrete implementation can be obtained.

d. Add the point to the original data.

(4) Repeat step (3) until all unknown points are simulated.
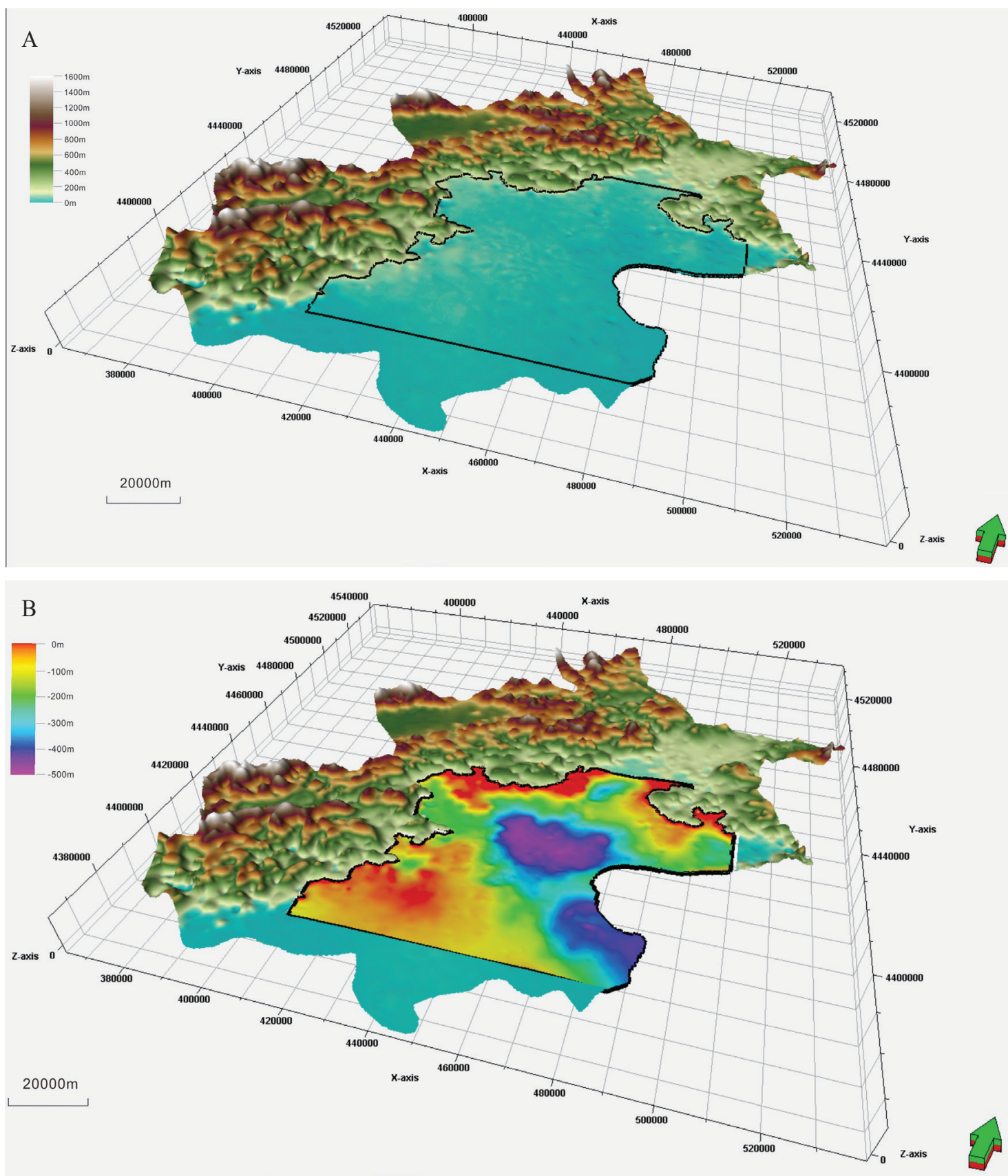

Figure 8. The framework of the model; A) the top surface of the model, B) the bottom surface of the model. 


\section{GEOLOGICAL MODELING}

\subsection{Data loading}

Drilling data provided by the Beijing Earthquake Agency (832 drills), was pre-processed and completed according to the loading format of the Petrel software and the well head data template, stratigraphic data template and lithological data template. Then, the drilling data in the study area were uploaded into the software.

The well head data was the basic data for the study area, and included four basic data, which were the well name, well coordinates, well elevation and well depth. As the drills used in this study are all safety evaluation drills, the true vertical depth (TVD) of all drills used in this research ranges from 50 to 350 metres (only through Quaternary sediments). Stratigraphic data is the basic data to build the top and basal framework of the model. Among these, the top data of the framework is the real elevation of each drill hole in the study area, and the basal data of the framework is the bottom depth of the Quaternary strata. Lithological data are the lithological information for each drilling hole, which needs to be loaded as the format of the well log.

According to the sequence of well head data, stratigraphic data and lithological data, the database establishment in the early stage of modeling was completed (Fig. 7).

\subsection{Construction of the model framework}

For this study, the drilling data were mainly used for safety evaluation. Unlike petroleum geological exploration, they generally do not have a seismic interpretation horizon. Therefore, how to determine a realistic top and base of the research area without adequate drilling was a key problem. The solutions, following (ZHAO \& LIU, 2007) were as follows:

(1) Download the Beijing Digital Elevation Model (DEM) from the Geospatial Data Cloud and use the Mosaic Tool in ArcGIS to mosaic and tailor the data.

(2) Convert the processed data into point files with corresponding elevation information and convert point files into data formats supported by the Petrel software using the Data Interoperability Tool in ArcGIS.

(3) Perform the interpolation operation of point files and conduct quality control using stratigraphic data. After interpolation, assign corresponding colours to different heights to reflect the real landforms of the study area.

(4) Clip the surface file formed in step (3) by using the boundary of the study area, to obtain the top surface of the model (Fig. $8 \mathrm{~A})$.

(5) Obtain the Quaternary sedimentary thickness contour map of the study area by reviewing the relevant literature (CAI et al., 2009a, 2009b). Vectorize and convert the thickness contour map into a point file with thickness information using ArcGIS (Fig. 9).

(6) Convert point files into data formats supported by Petrel software using the Data Interoperability Tool in ArcGIS, then interpolate the point files into a thickness surface using Petrel.

(7) Perform the subtraction operation on the top and thickness surfaces using Petrel to form the basal surface of the model (Fig. 8B).

In summary, this method will retain the geomorphological characteristics of Beijing to the greatest extent and reflect the real surface and underground information of the study area.

When the establishment of the top and bottom of the model was finalized, the horizontal and vertical grids were built based on these surfaces. Four vertical grid building methods are provided in Petrel: according to the trend of the top surface of the model (Fig. 10A); according to the trend of the bottom surface of the model (Fig. 10B); according to the proportion of manual settings (Fig. 10C); and according to the number of vertical layers by the equal proportion (Fig. 10D). There is no precise seismic data in this study, so the distribution law of underground strata in the study area is not known. For this reason, the fourth method is chosen in this model. After testing, setting the number of vertical layers to 400 can achieve higher accuracy. Finally, the adjustment of relevant parameters of the geological modeling was conducted.

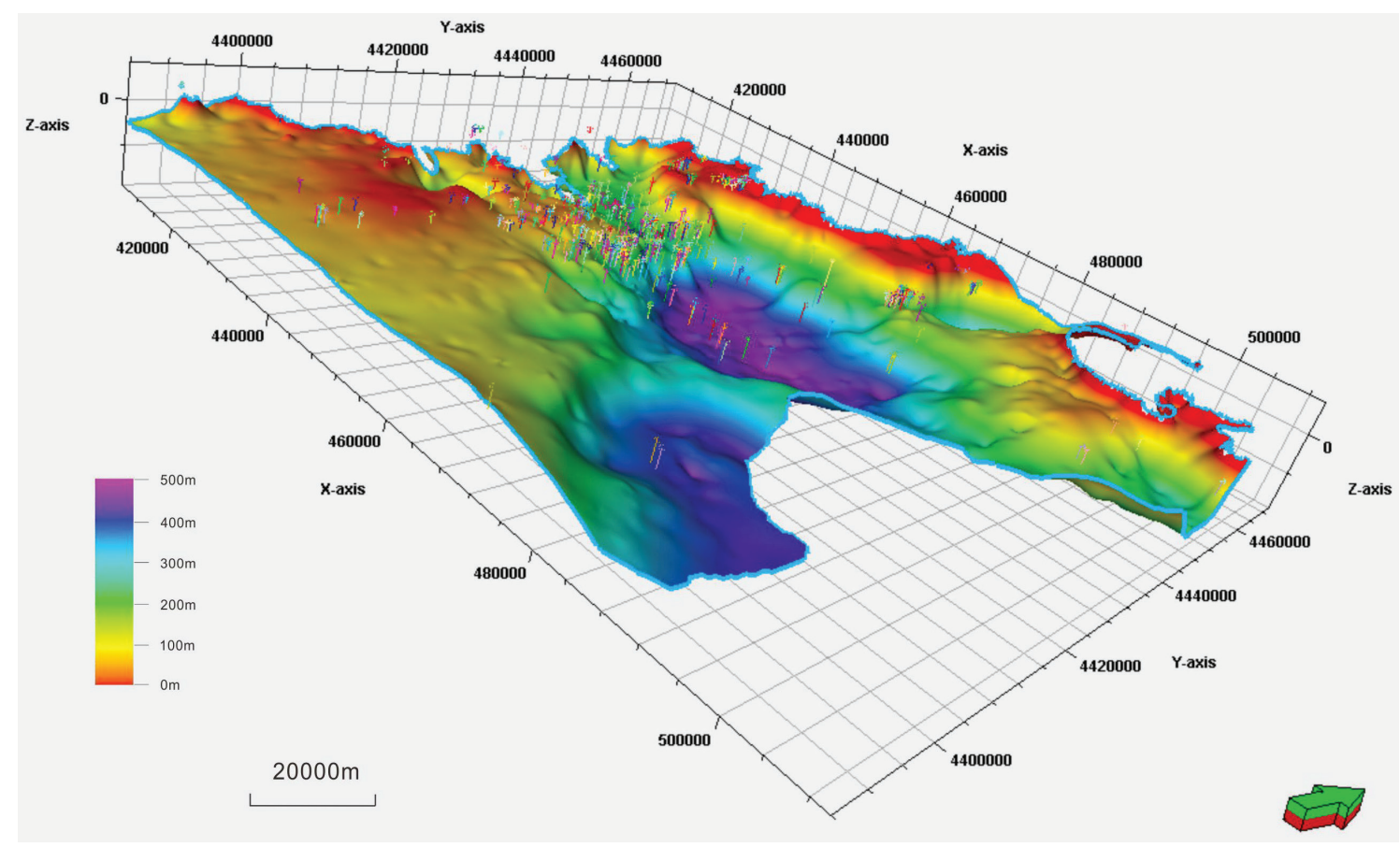

Figure 9. Thickness distribution of the Quaternary strata. 
A

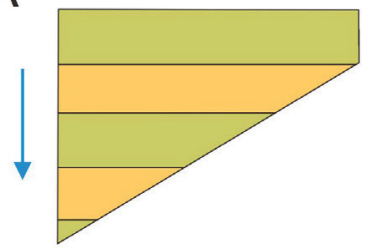

C

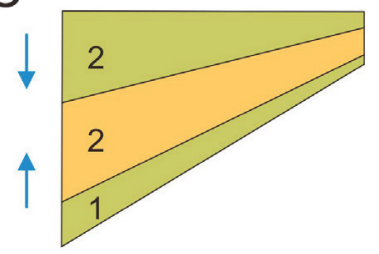

B

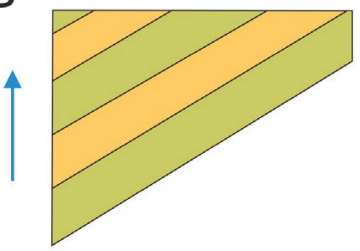

$\mathrm{D}$

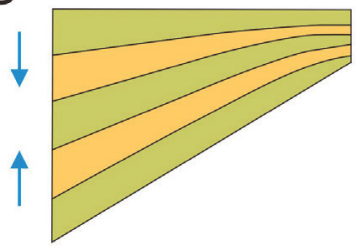

Figure 10. Four vertical grid building methods; A) follow top, B) follow base, C) manual settings, D) equal proportion.

\subsection{Computation of the variogram}

After the model framework has been established, we simulated the main lithology of the study area. Due to the confidentiality of relevant data, only five main lithologies were selected in this study area, each lithologic code and its percentage content is shown in Table 1. The anthropogenic layer (backfill) is widely distributed over the surface of the study area after the extensive human development and transformation in Beijing. Therefore, the overall distribution of backfill does not conform to the sedimentary law of the study area. In order to reflect the true three-dimensional structure of Quaternary sediments, backfill was not added to lithological modeling in this study.

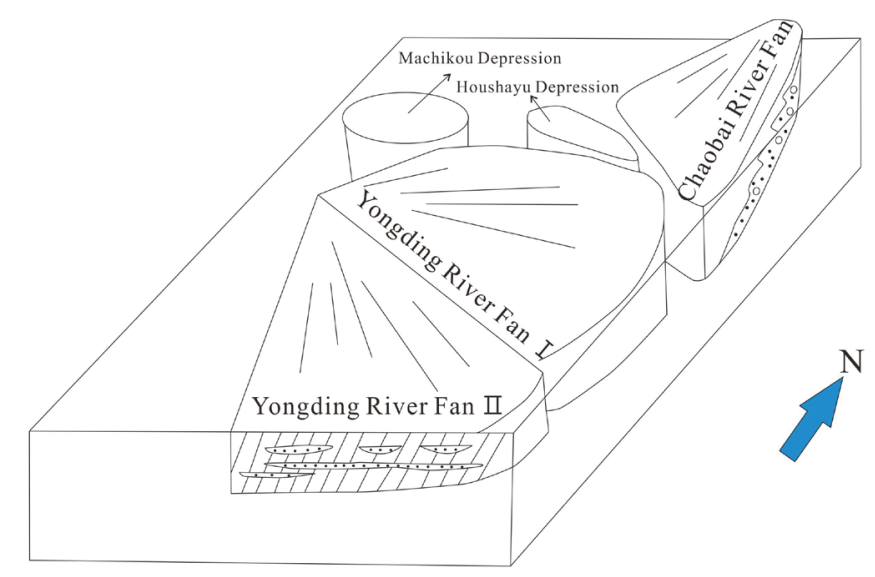

Figure 11. Sketch map showing Quaternary geological units and their combination in the Beijing plain (modified from CAl et al., 2009a).

The selection of the major direction in the variogram is the most important part in the whole process. The main direction represents the direction with the best correlation among the sample points, which has the largest range. The scale of variation not only reflects the change of regional variables in a certain direction, but also reflects the average scale of the carrier of regional variables (such as lithology in the model) in a certain direction. Therefore, in order to realize the analysis of the underground three-dimensional structure in the study area, the range can be used to predict the extension size of lithology in a particular direction. LI et al. (1999) argued that before stochastic simulation, the spatial structure of sedimentary facies should be considered comprehensively to determine the ellipse size used to search the simulated grid points and conditional data around a grid node. In

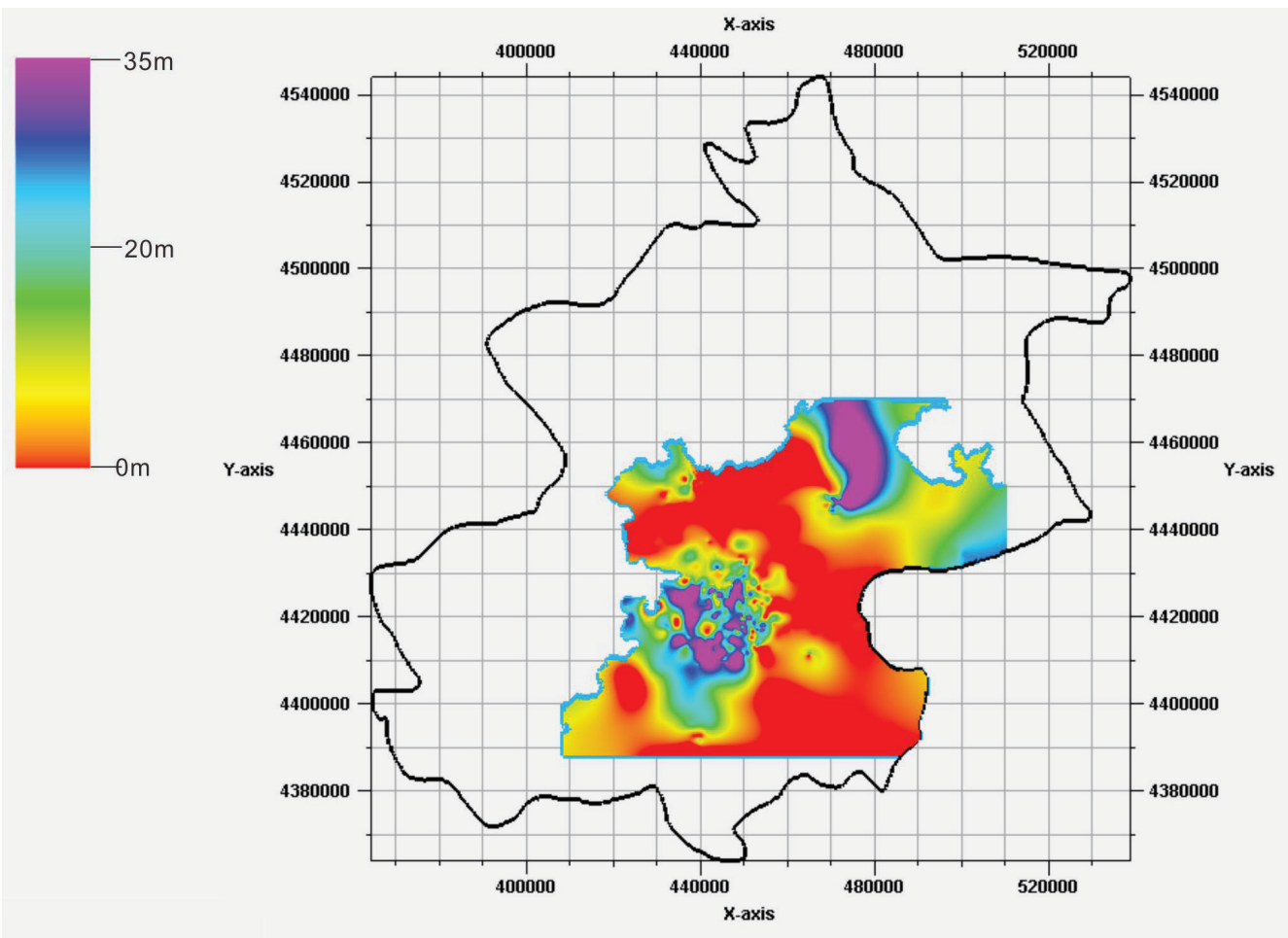


Table 1. Variogram parameters of lithology in the study area.

\begin{tabular}{|c|c|c|c|c|c|c|}
\hline Codes & Lithology & Percentage (\%) & Major Range $(\mathrm{m})$ & Minor Range $(\mathrm{m})$ & Vertical Range $(\mathrm{m})$ & Major Direction $\left({ }^{\circ}\right)$ \\
\hline 1 & Pebble & 25.1 & 13911 & 11845 & 30 & 287 \\
\hline 2 & Silty Clay & 25.8 & 10528 & 9049 & 23 & 307 \\
\hline 3 & Sand & 13.0 & 5819 & 4950 & 15 & 320 \\
\hline 4 & Clayey \& Sandy Silt & 11.0 & 5917 & 3582 & 11 & 323 \\
\hline 5 & Other Lithology & 22.8 & 10872 & 7185 & 21 & 303 \\
\hline
\end{tabular}

addition, the number of simulated grid points and conditional data needed to simulate a grid point should also be considered comprehensively. Based on this theory, DUAN et al. (2007) holds that in practice, two methods can be used to determine the major direction and verify each other. One is to refer to the sedimentary facies map and the other is to examine the contour line or trend surface map of certain attributes.

The Cenozoic of Beijing inherited the tectonic framework of the late Mesozoic. From the end of the Cretaceous to the Pliocene, there was a very large ancient lake (fault basin) in the Beijing Plain, which (the Beijing ancient lake). The lake surface expanded and the lake water became deeper during the Neogene. During the Pliocene, the rise of the Xishan Mountain accelerated, the ancient lake of Yanqing formed and the water surface gradually expanded. The ancient Yongding River was eroded by fissures along the axis of the Youzhou anticline. When the water level of the ancient lake in Yanqing was high, the fissures along the axis of the Youzhou anticline were connected with the ancient Yongding
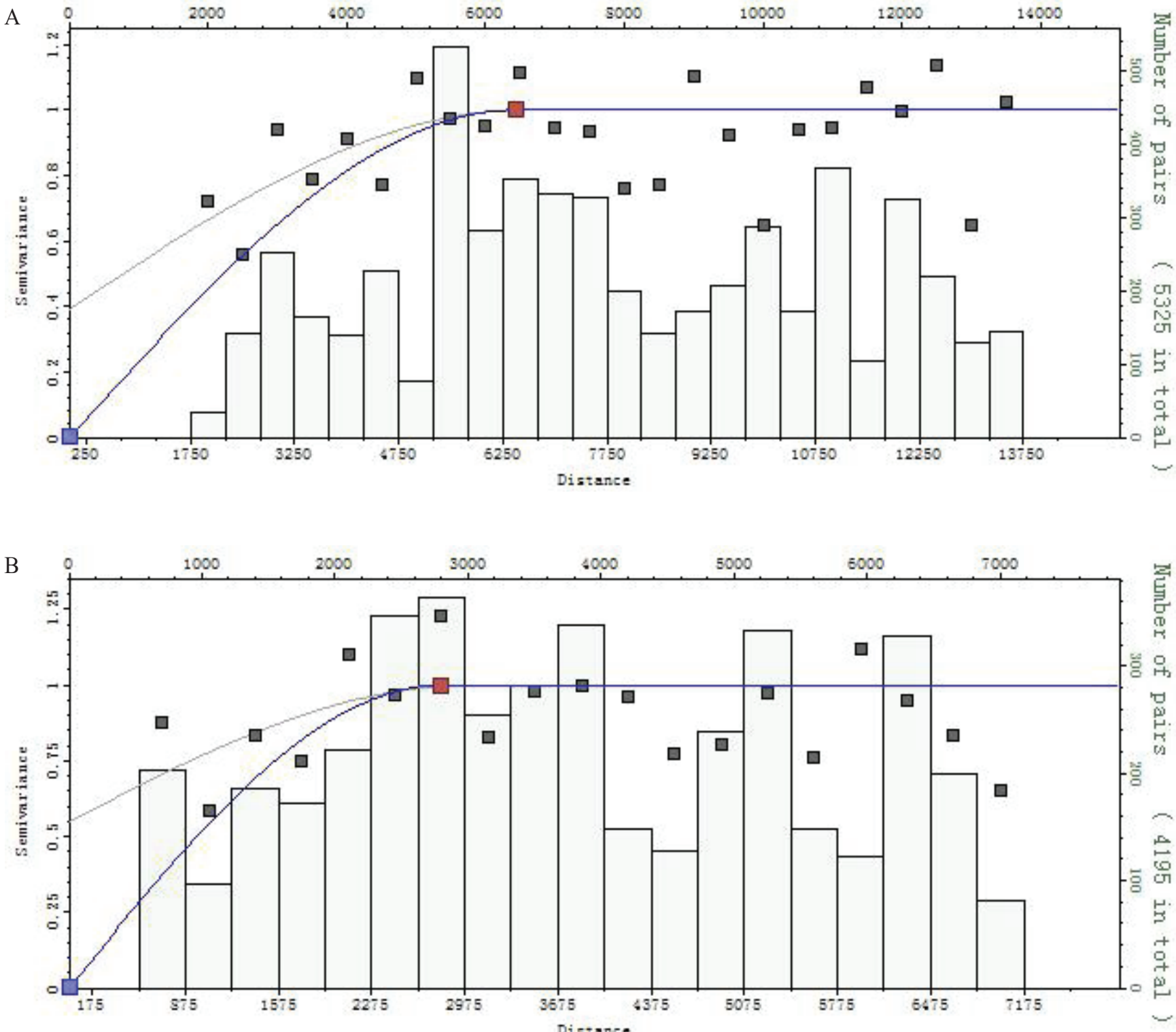

Figure 13. Variogram models of each lithology in the study area; A) variogram model of other lithology in the major direction, B) variogram model of other lithology in the minor direction. 

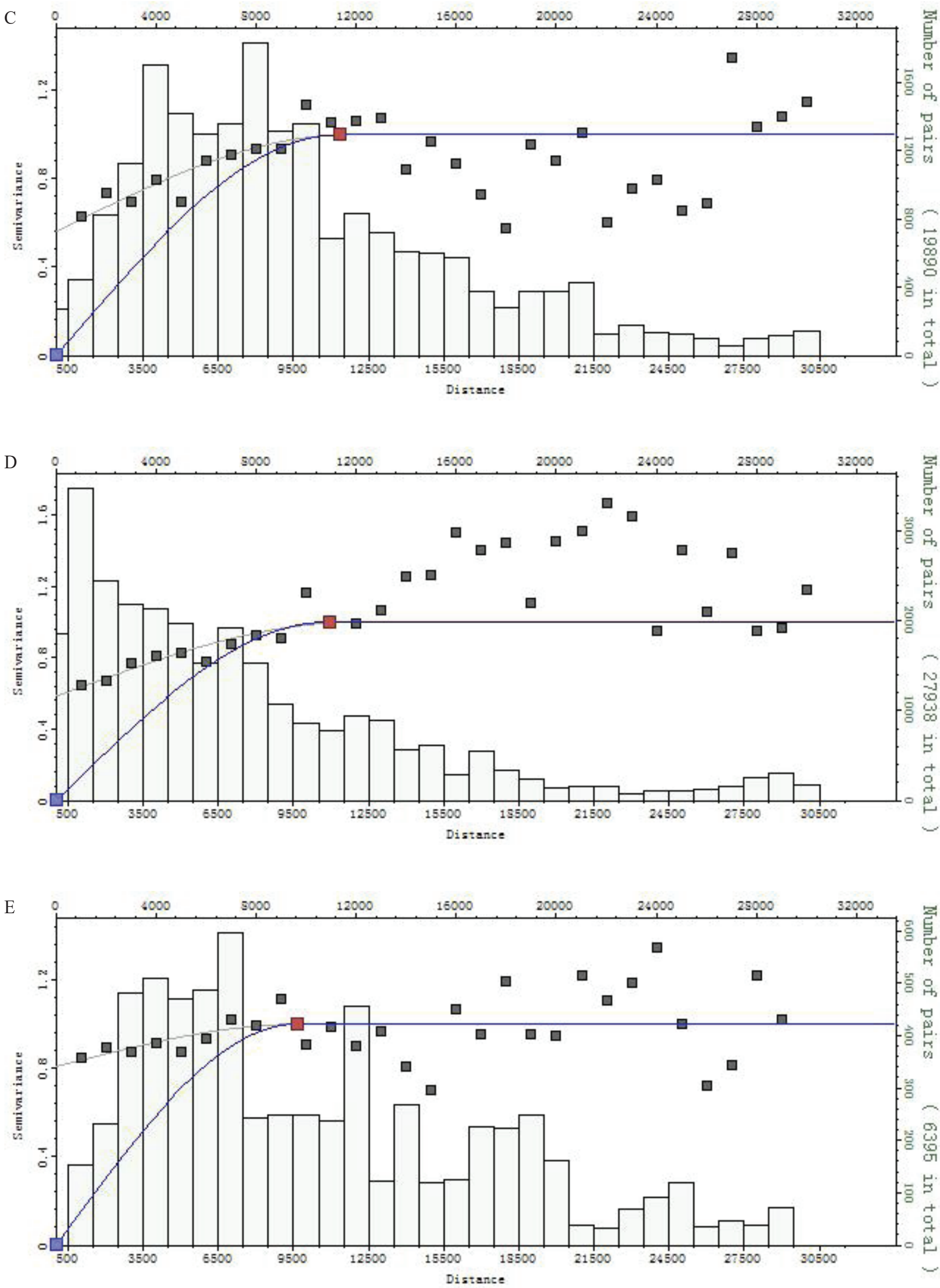

Figure 13. Continued. C) variogram model of pebbles in the major direction, D) variogram model of pebbles in the minor direction, E) variogram model of silty clay in the major direction. 

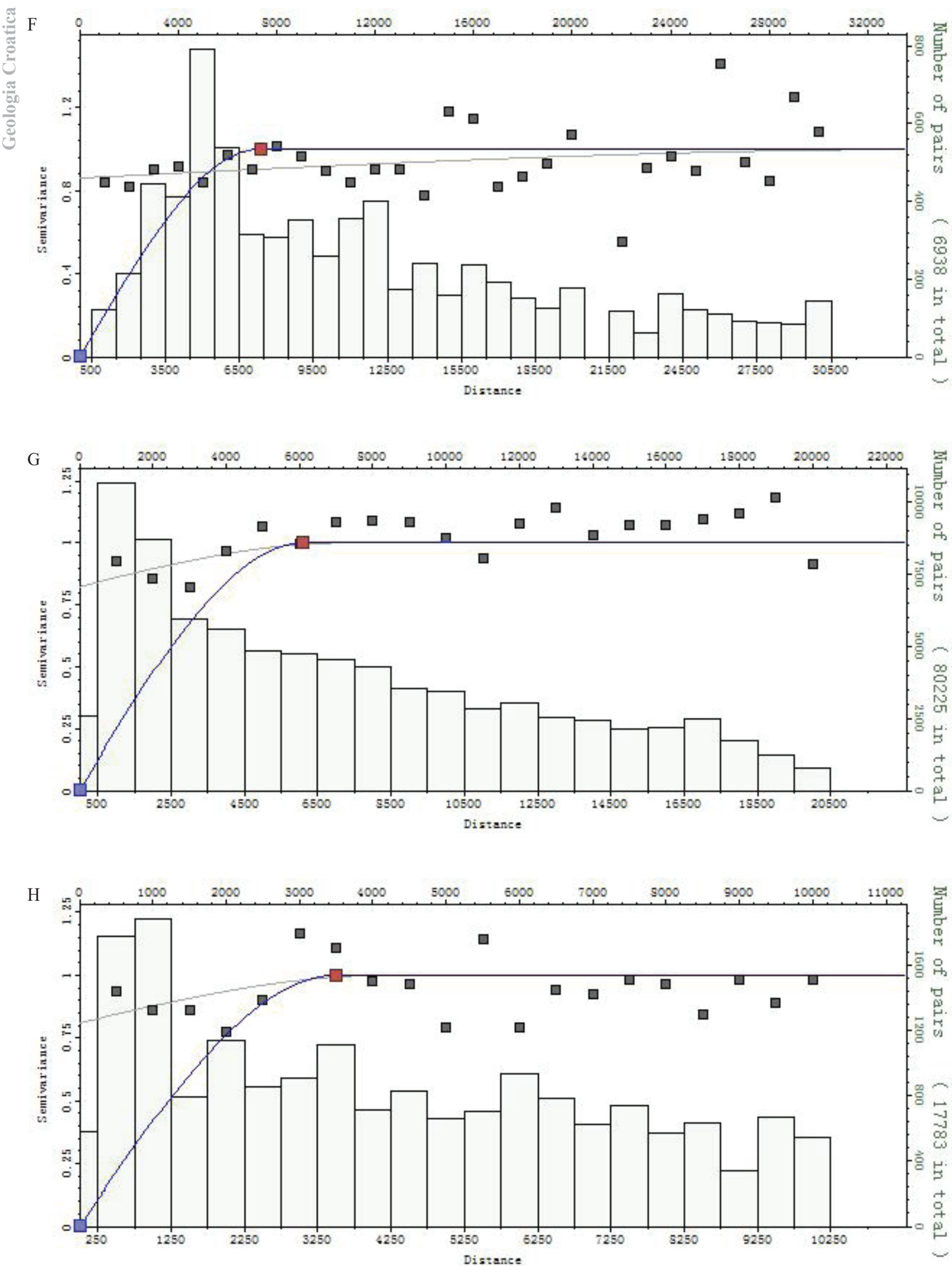

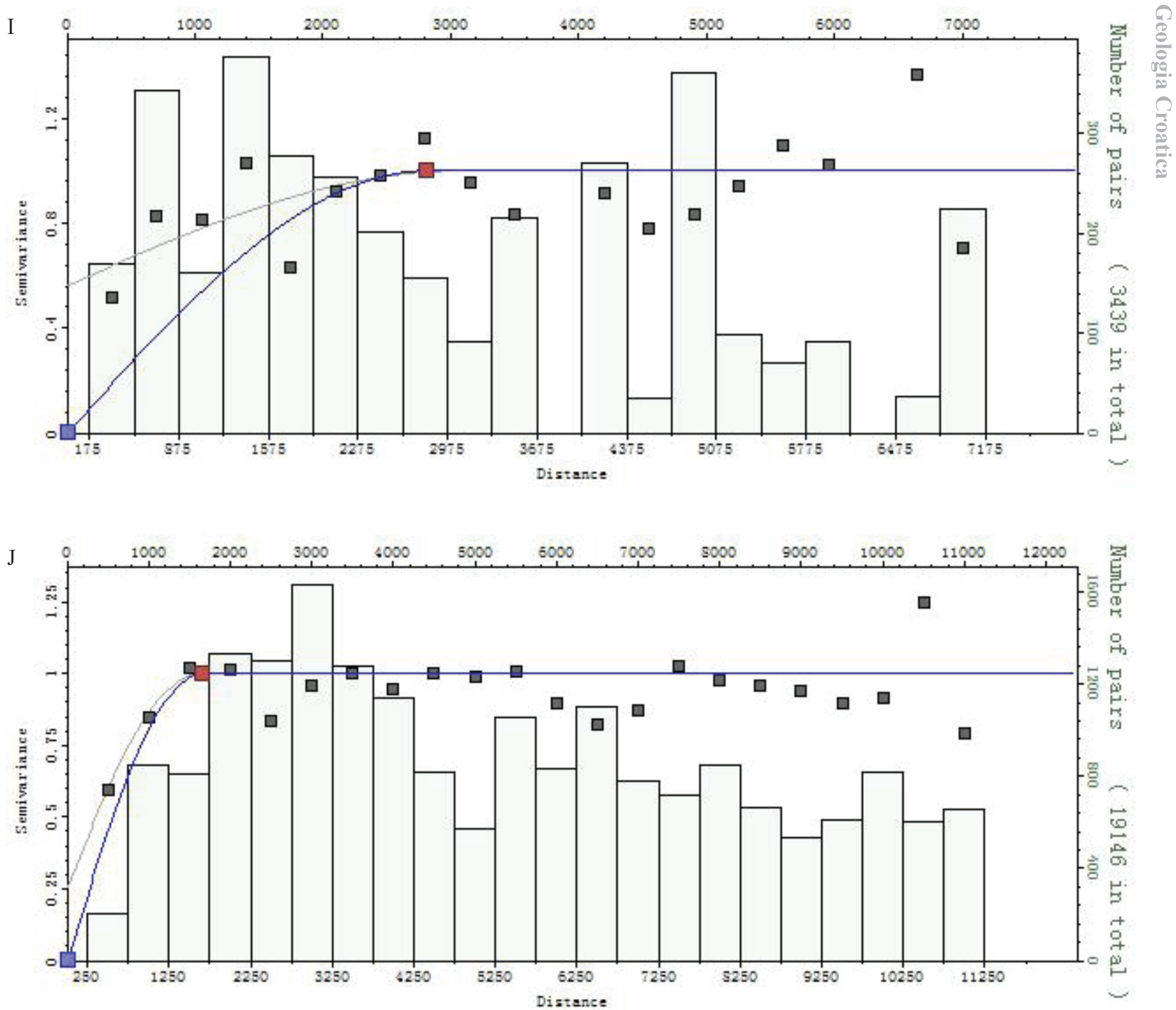

Figure 13. Continued. I) variogram model of clayey \& sandy silt in the major direction, J) variogram model of clayey \& sandy silt in the minor direction.

River to form pulsating floods, and more than ten layers of diluvium were formed in the ancient lake in Beijing. In the middle of the Pliocene, from 3.33 Ma to $3.58 \mathrm{Ma}$, the high-water level of the Yanqing Ancient Lake broke through the last obstacle of the gorge section, and an unprecedented great flood occurred. The Yongding River was formed which carries a large amount of gravel and sediment, eventually filling up the ancient lake in Beijing, and the huge river fan group in Beijing began to form. After the formation of the Yongding River, and due to the activities of Huangzhuang-Gaoliying fault and Yongding River fault, the outlet of the Yongding River moved from Junzhuang to Sanjiadian. After the rivers emerged from the mountains, they changed their courses many times due to tectonic movement, and gradually moved from north to south. The large river fans formed by each diversion of the Yongding River overlapped with each other and eventually shaped the present Beijing Plain. Quaternary sediments extensively covered the Beijing Plain. Its sedimentary system is composed of two large fans, which are the Yongding River fan and the Chaobai River fan. The Yongding River was further divided into the No. 1 fan of the Yongding River and the No. 2 fan of the Yongding River (CAI et al., 2009). The Yongding River fan mainly covers the study area, with the overall sedimentary direction of fans I and II of the Yongding River being NW-SE (Fig. 11). In addition to analyzing the distribution characteristics of pebble deposits, the major direction of NW-SE can also be observed (Fig. 12). From this, the range's major direction of all lithologies in the study area can be preliminarily determined.

After the main directions were established, the variogram model of each lithology was developed by further statistical analysis of the drilling data (Table 1, Figure 13). As can be seen in Figure 13, although the variogram models of this research were not as typical as Figure 5, their degrees of fit were better.

\section{PRELIMINARY ANALYSIS OF THE THREE-DIMENSIONAL STRUCTURE OF QUATERNARY}

With the use of variogram models, five equal probability models of the Quaternary were generated for the study. Through discus- 


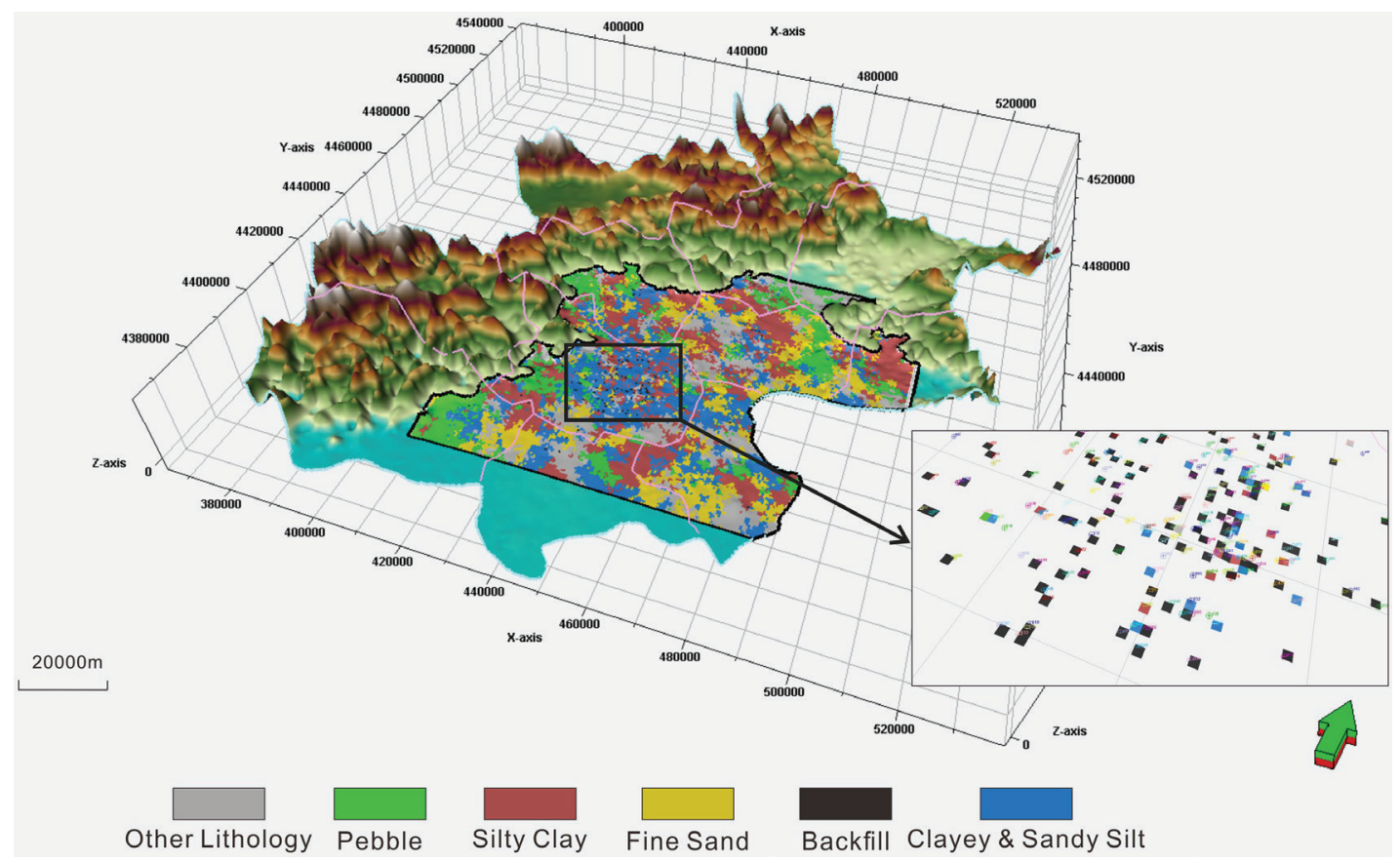

Figure 14. Geological model of the study area (with backfill of surface).

sion with experts, a relatively accurate model was finally selected. As shown in Figure 14, although backfill was not included in the modeling process, the software can replace the location of drills in the model with the corresponding drill information. While this can be used for model checking, it can also allow researchers to observe the distribution of the anthropogenic layer. The drill holes in the central part of the study area (urban area of Beijing) are all backfill, demonstrating that the surface of the urban area of Beijing has undergone a great anthropogenic transformation. Although the anthropogenic layer is widely distributed in the urban area of Beijing, its single layer thickness is relatively thin $(10 \mathrm{~m})$.

After surface analysis, it was observed that the silty clay deposits in the middle of the study area gradually decreased and the pebble deposits gradually spread to the middle of the study area (Fig. 15). Continuous downward observation of the model

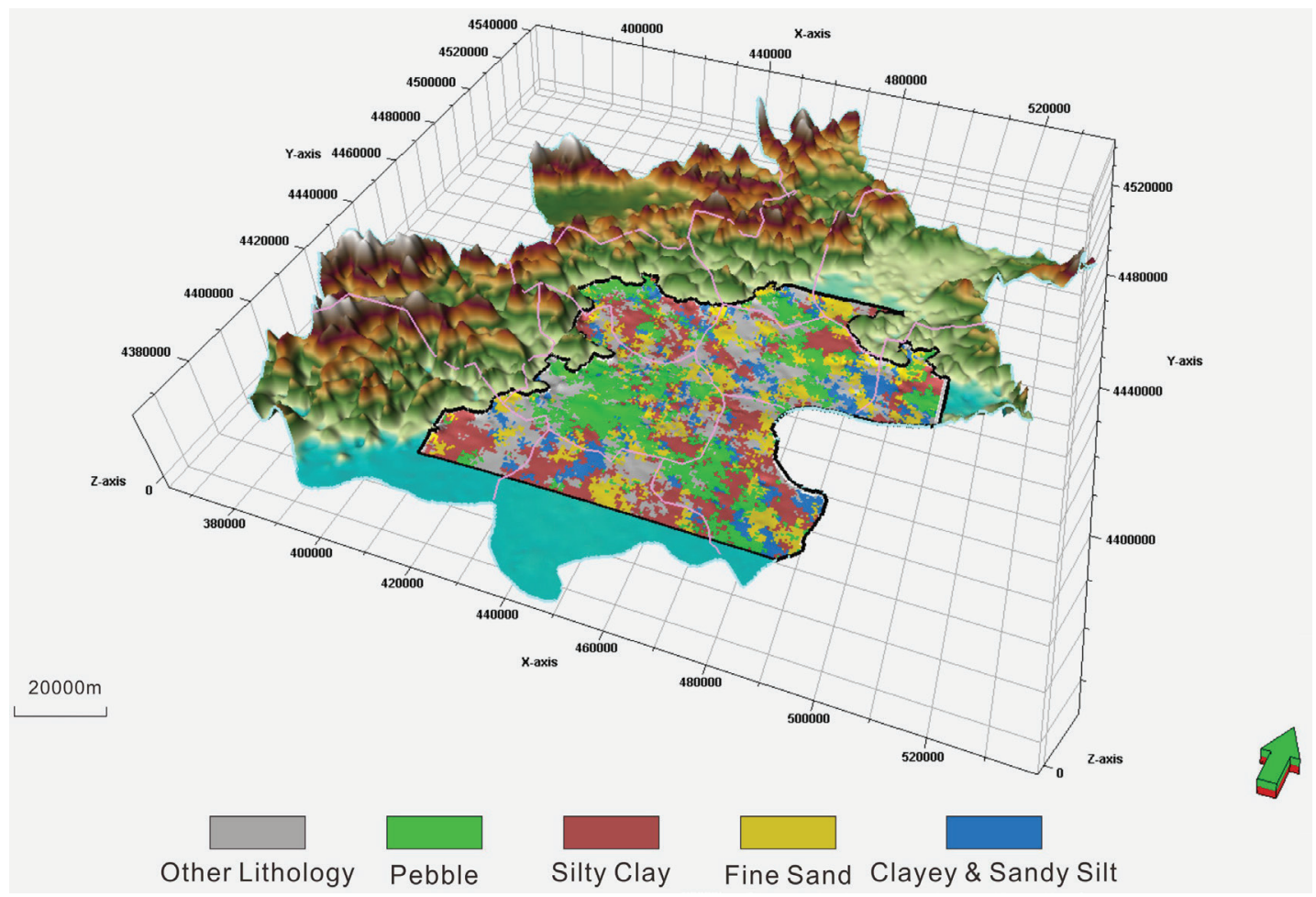

Figure 15. Geological model of the study area (the 50 layer of model). 


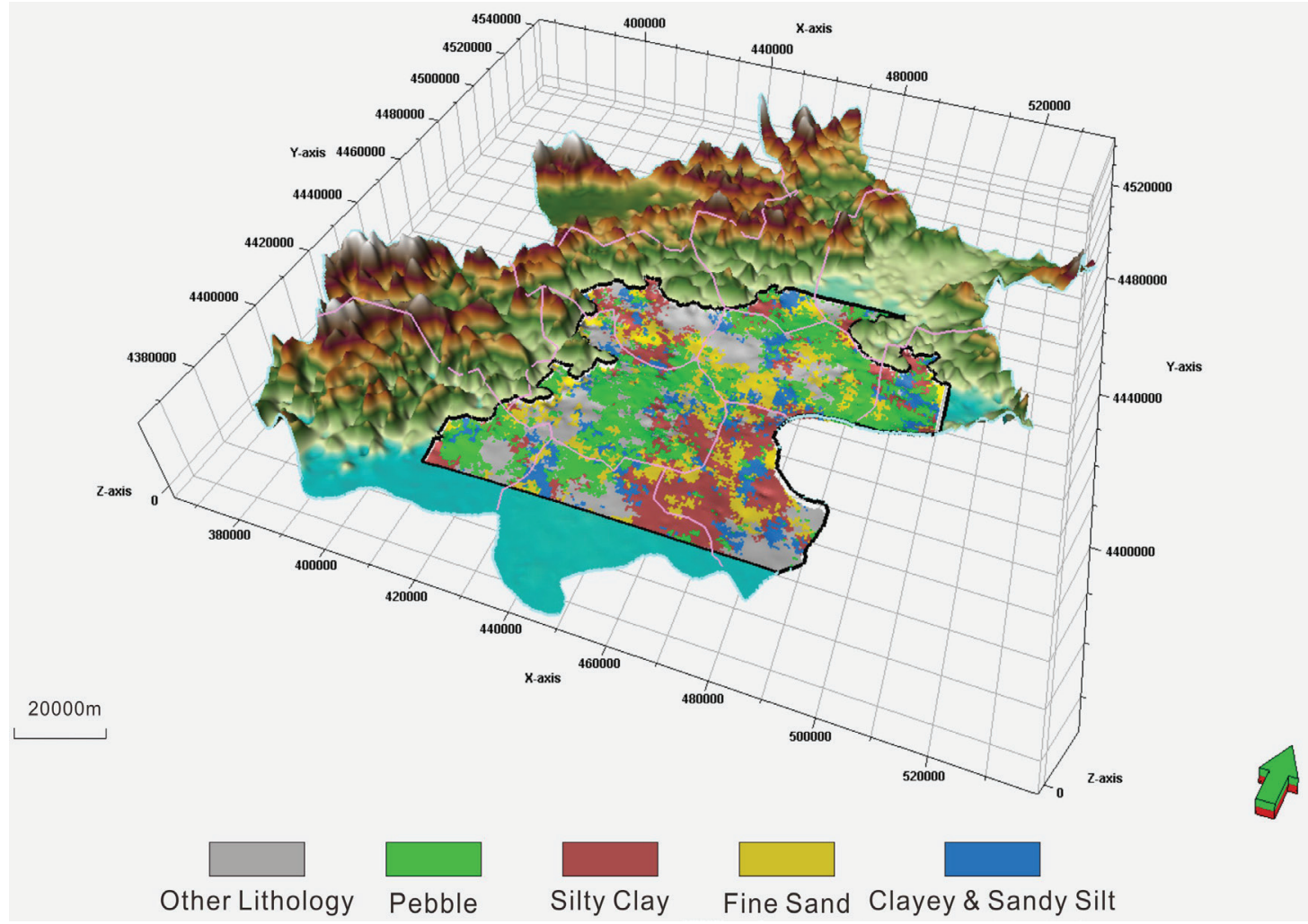

Figure 16. Geological model of the study area (the 175 layer of model).

(Fig. 16) shows that the pebble deposits still show a trend of spreading throughout the region. Furthermore, the older deposits such as sandstone, silt and clay deposits gradually replace some younger deposits such as pebbles in the southeastern part of the study area. At the bottom of the model (Fig. 17), it can be seen that the younger deposits such as pebble deposits are clearly reduced, and the older silt and clay deposits are clearly increased.

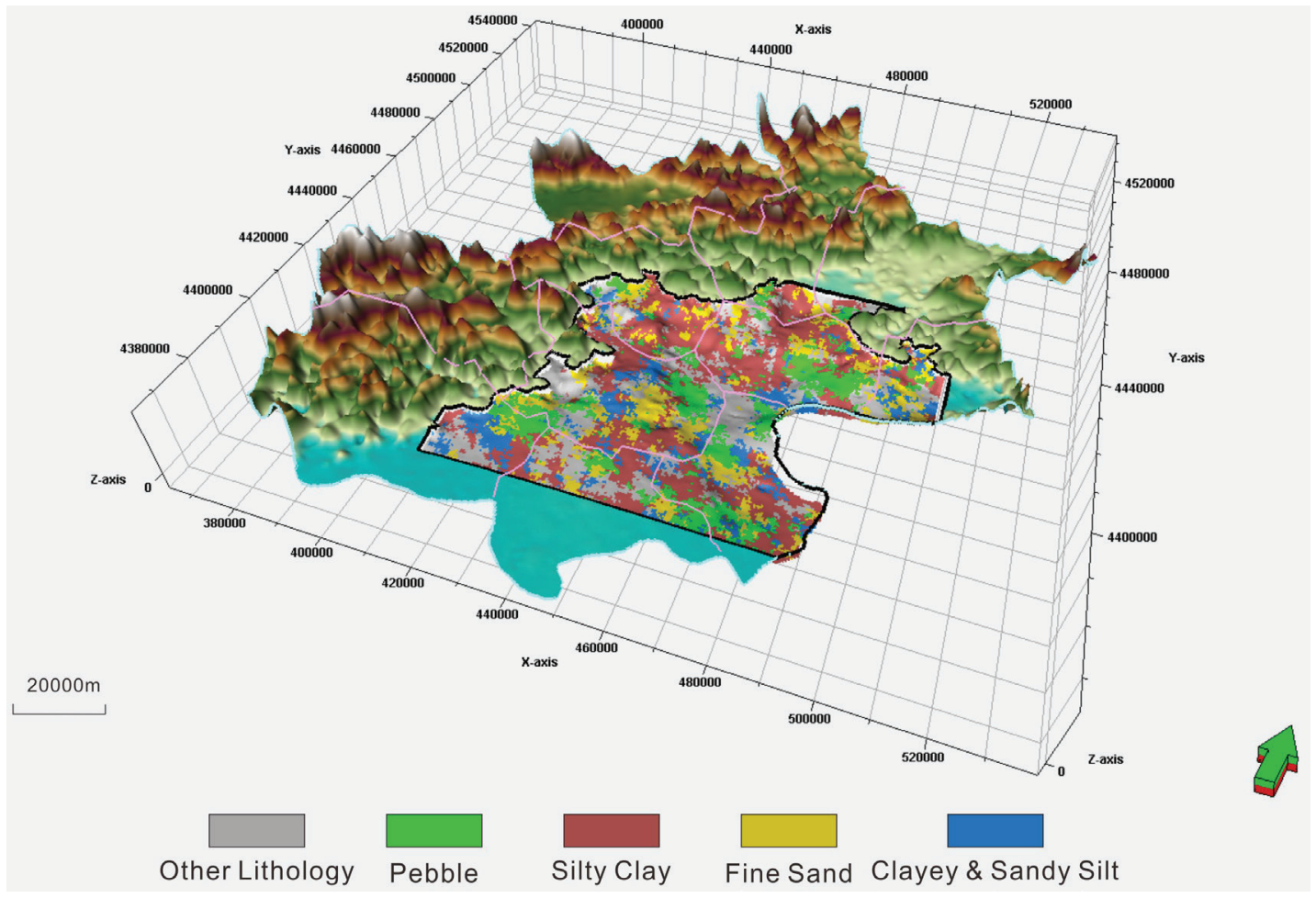

Figure 17. Geological model of the study area (the 373 layer of model). 


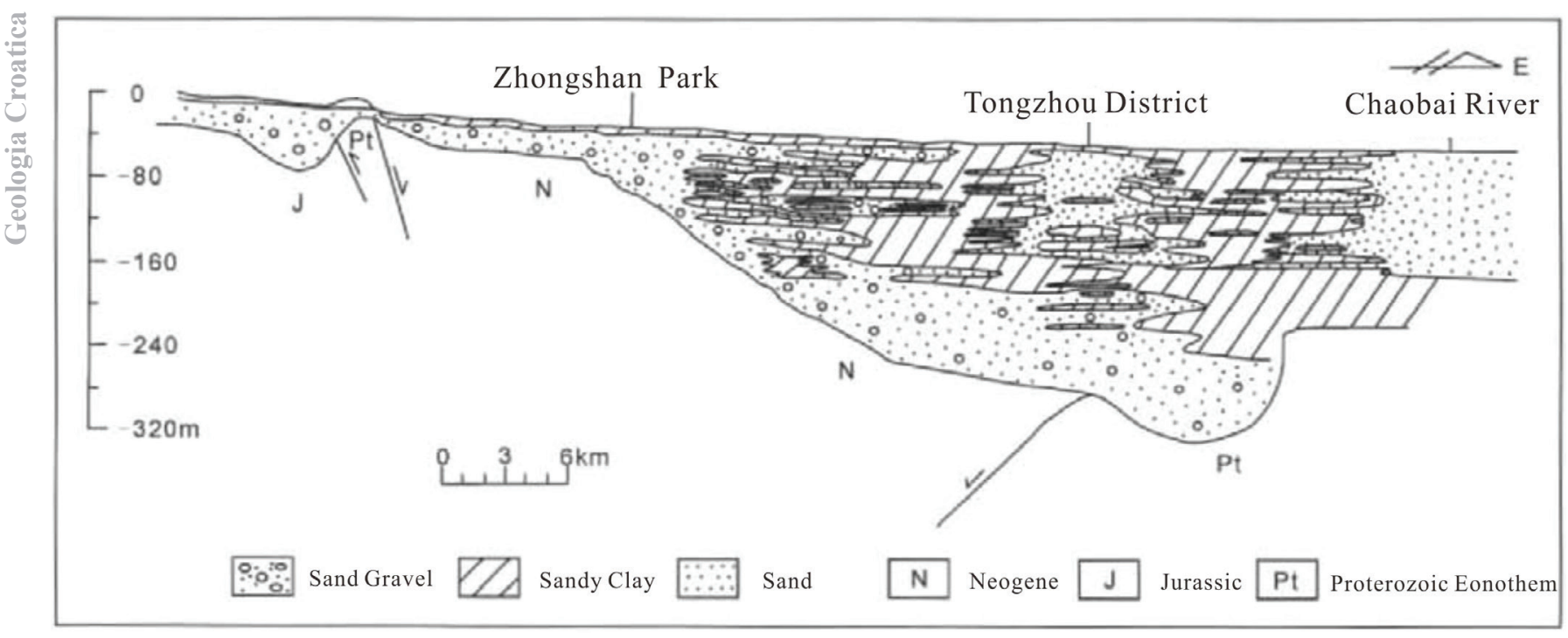

Figure 18. Schematic diagram of the geological section of the River fan (modified from CAl et al., 2009).

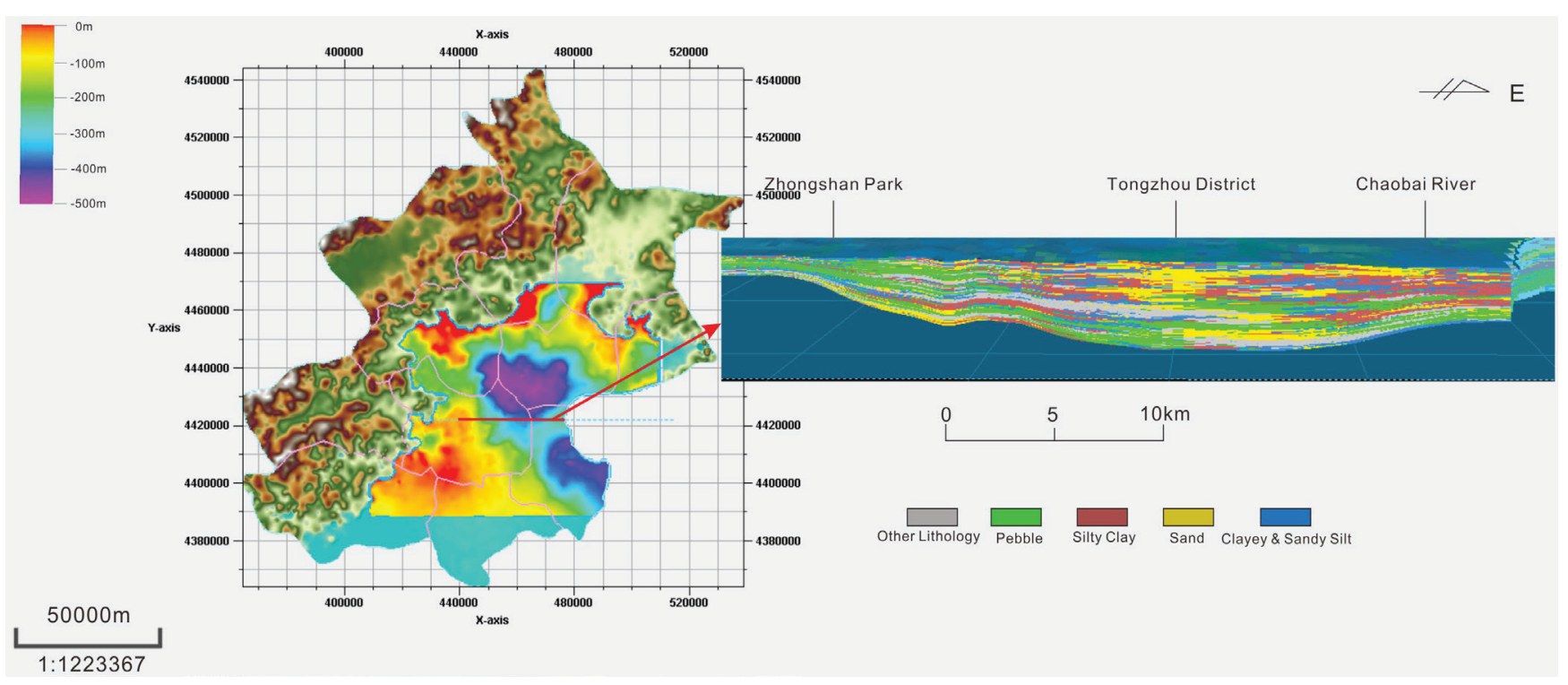

Figure 19. Geological section of the depocentre in the study area.

The observational results of vertical characteristics of the Quaternary sediment show that at the top of Quaternary strata, the coarse-grained sediments such as pebbles and sandstones are mostly distributed at the edges of the study area. The fine-grained sediments such as silt and clay are mostly distributed in the depositional centre of the study area. In the middle of Quaternary strata, pebble is mainly deposited. To the bottom of the Quaternary strata, pebble deposits are replaced by some silt and clay fine-grained deposits. The Tongzhou District (southeast of the study area) is the depositional centre of the No. 1 Fan of the Yongding River. It can be seen from the geological profile (Fig. 18) that the two predominant kinds of coarse-grained sediments are mainly gravel and sand, with fine-grained sediments and sand in the middle. Longitudinal observation of the model profile (Fig. 19) shows that the top and bottom sediments in the Tongzhou area are primarily sandstone and pebble sediments, with finegrained sediments and sand sandwiched in the middle. The overall vertical sedimentary law is approximately consistent with the actual sedimentary law.

\section{CONCLUSION}

Firstly, based on the sedimentary regularity of the Quaternary alluvial fan in the Beijing Plain area and the regular distribution of lithological thicknesses in the study area from known drilling data, lithological variogram models were established. The threedimensional geological model of the Quaternary in Beijing was then developed using the sequential indicator simulation method.

Secondly, through the verification of the model and examples, it shows that the model is accurate and can be used for researchers to preliminarily understand the distribution characteristics of Quaternary strata in Beijing plain.

In summary, this study utilized the integration of drilling information, a digital elevation model, a stratum sedimentary thickness plan and other data on the same platform. Besides, the methodology shown here will provide researchers with a preliminary understanding of the underground three-dimensional structure of the study area. More importantly, it plays an important role in the establishment of earthquake early warning system, 
active fault detection and land subsidence analysis. The author believes that with the increase of drilling data in the later period, the model can describe the Quaternary strata more precisely.

\section{ACKNOWLEDGEMENT}

National Key R\&D Program of China (Grant No. 2017YFC1500604), the National Natural Science Foundation of China (Grant No. 51708524) and the Program for Innovative Research Team in China Earthquake Administration (Earthquake Disaster Simulation and Evaluation in mainland of China) supported this study. We are very thankful to all the researchers of the Beijing Earthquake Agency for access to the drilling data. We also thank Professor Sun BAITAO for his assistance with choosing the topic, defining the conceptual framework and revising the manuscript.

\section{REFERENCES}

ANTOINE, P., ROUSSEAU, D.-D., DEGEAI, J.-P., MOINE, O., LAGROIX, F., KREUTZER, S., FUCHS, M., CHRISTINE, H., GAUTHIER, C., SVOBODA, J. \& LISÁ, L. (2013). High-resolution record of the environmental response to climatic variations during the Last Interglacial-Glacial cycle in Central Europe: The loess-palaeosol sequence of Dolní Věstonice (Czech Republic).- Quaternary Science Reviews, 67, 17-38. doi: 10.106/j.quascirev.2013.01.014

BRKIĆ, Z. (2017): The relationship of the geological framework to the Quaternary aquifer system in the Sava River valley (Croatia).- Geologia Croatica, 70/3, 201-213. doi: $10.4154 / \mathrm{gc} .2017 .12$

CAI, X.M., GUO, G.X., LUAN, Y.B. \& LIANG, Y.N. (2009b): Quaternary geological features of Beijing piedmont plain using 3-D structural method.-Acta Geologica Sinica, 83/7, 1047 1056.

CAI, X.M., LUAN, Y.B., GUO, G.X. \& LIANG, Y.N. (2009a): 3D Quaternary geological structure of Beijing plain.- Geology in China, 36/5, 1021-1029.

CAI, X.M., ZHANG, L., GUO, G.X., YOU, S.N., FANG, T.M., LV, J.B. \& LIANG, Y.N. (2016): New progress in the study of Quaternary geology in Beijing plain.- Geology in China, 43/3, 1055-1066. doi: 10.12029/gc20160327.

CAO, D.Y. \& WANG, Z.G. (2004): Direct 3D-Interaction in 3D geological model visualization.- Journal of China University of Mining \& Technology, 33/4, 384-387.

CLAYTON, V. D. \& ANDRE, G. J. (1998): GSLIB: Geostatistical software library and user's guide, second edition.- USA: Oxford University Press.

DUAN, T.X., LIU, X.M., ZHANG, Y.J. \& XIAO, S.Q. (2007): Discussion on geologic modeling with petrel.- Lithologic Reservoirs, 19/2, 102-107.

FENG, G.Q., LI, Y., LIN, Z.H. \& WANG, Y.M. (2001): Application of sequential indicator simulation method to delineating sedimentary microfacies.- Journal of Southwest Petroleum Institute, 23/2, 1-2.

GRIZELJ, A., BAKRAČ, K., HORVAT, M., AVANIĆ, R. \& HEĆIMOVIĆ, I. (2017): Occurrence of vivianite in alluvial Quaternary sediments in the area of Sesvete (Zagreb, Croatia).- Geologia Croatica, 70/1, 41-52. doi: 10.4154/gc.2017.01.

GUO, G.X., LUAN, Y.B., YE, C. \& CAI, X.M. (2008): Discussion on the lower boundary of Quaternary system and its application in the Beijing plain.- City Geology, $13 / 2,13-16$

HAO, S.G., MA, X.P., XIA, Z.K., ZHAO, C.H., YUAN, S.X. \& YU, J.C. (2002): The early Holocene loess section in the Donghulin site near Zhaitang in Beijing.- Journal of Integrative Plant Biology, 167/13, 420-429.

KONG, Z.C. \& DU, N.Q. (1980): Vegetational and climatic changes in the past $30000 \sim 10000$ years in Beijing.- Journal of Integrative Plant Biology, 22/4, 330-338.

LEHMKUHL, F., POTTER, S., PAULIGK, A. \& BOSKEN, J. (2018): Loess and other Quaternary sediments in Germany.- Journal of Maps, 14/2, 330-340. doi: 10.1080/17445647.2018.1473817.

LI, C.A. (1994): Late Cenozoic stratigraphic division and establishment of stratigraphic succession in the northeast of the Beijing plain.- Journal of Stratigraphy, 18/2, $138-145$.

LI, D.R., PENG, Y.M. \& LIU, Q.S. (1979): Subdivision of Pliocene-Pleistocene series in Beijing plain.- Geological Sciences, 4, 342-349.

LI, L.Y. \& CHEN, H.H. (1992): Comprehensive criteria for the N/Q boundary in Huairou area, Beijing, China.- Earth Science, 17/6, 631-637.
LI, L.Y. \& CHEN, H.H. (1994): On magnetostratigraphy of the borehole HR88-1 in Huairou area, Beijing.- Journal of Stratigraphy, 18/1, 39-44.

LI, S.H., ZHANG, C.M. \& TANG, J. (1999): Application of sequential indicator simulation method and its application in Pucheng Oilfield reservoir heterogeneity.Journal of Jianghan Petroleum Institute, 21/1, 13-17.

LI, T.T. \& WEI, B. (2015): Application of petrel in multi-point statistical geological modeling.- Petrochemical Industry Technology, 11, 105.

LIU, Y. \& ZHOU, K.F. (2018): Gold anomaly identification and its uncertainty analysis in the West Junggar Belt, Xinjiang.- Earth Science, 43/9, 3186-3199. doi: 10.3799/dqkx.2018.151

LUAN, Y.B., GUO, L., GUO, G.X. \& HUANG, X. (2008): Geochemical character of trace elements from well N5 in the Quaternary sediments and research of Palaeoclimate, palaeoenvironmental.- City Geology, 13/13, 18-22.

PAN, M., FANG, Y. \& QU, H.G. (2006): Discussion on several foundational issues in three-dimensional geological modeling.- Geography and Geo-Information Science, $23 / 3,1-5$.

SHAN, Q.S., YANG, H.L. \& LIU, L.G. (1994): The environmental evolution of Quaternary of Beijing Tongxian region.- Beijing Geology, 4, 1-7.

SHEN, Y.Y., GUO, G.X., XIN, B.D., XU, L. \& LIU, J.R. (2015): Three-Dimensional geological structure model based on GMS in Shunyi and Pinggu districts.- Beijing. Urban Geology, 10/2, 67-71.

SONG, J.B., TIAN, T. \& GAO, P. (2016): Reservoir modeling of Chang 6 in Shijia oil block, Qingpingchuan Oilfield, Ordos Basin.- Geology of Shanxi, 34/1, 19-24.

TERHORST, B., KUHN, P., DAMM, B., HAMBACH, U., MEYERHEINTZE, S. \& SEDOV, S. (2013): Palaeoenvironmental fluctuations as recorded in the loess-palaeosol sequence of the upper palaeolithic site Krems-Wachtberg.- Quaternary International, 351, 67-82. doi: 10.1016/j.quaint.2013.03.045

VELIĆ, J. \& DURN, G. (1993): Alternating Lacustrine-Marsh Sedimentation and Subaerial Exposure Phases During Quaternary: Prečko, Zagreb, Croatia.- Geologia Croatica, 46/1, 71-90.

VELIĆ, J., SAFTIĆ, B. \& MALVIĆ, T. (1999): Lithological Composition and Stratigraphy of Quaternary Sediments in the Area of the Jakuševec Waste Depository (Zagreb, Northern Croatia).- Geologia Croatica, 52/2, 119-130.

WANG, H. (2017): Application of geostatistics method in reservoir modeling.- Petrochemical Industry Application, 36/10, 58-60. doi: 10.3969/j.issn.1673-5285.2017.10.014

WANG, J.R., HU, L.T. \& YIN, W.J. (2014): Comparison of 3D geological modelings in Beishan Gansu province.- Journal of Beijing Normal University (Natural Science), $50 / 5,478-482$.

WEI, L.Y., PENG, G. \& YAN, F.H. (1997): Climatic changes and their environmental effects during the last deglaciation in Beijing area.- Quaternary Sciences, 2, $183-191$.

YAO, Y.F., YE, C., KOU, X.Y., XU, J.X., JIA, S.M., DU, N.Q. \& LI, C.S. (2007): Vegetation succession and climate changing since the Late Pliocene in Tianzhu Region in Beijing.- Journal of Palaeogeography, 19/11, 45-58.

YUAN, B.Y., DENG, C.L., LU, J.B., JIN C.Z. \& WU, Y.S. (2002): A late Quaternary accumulation period and the Prehistoric flood in Beijing plain.- Quaternary Sciences, $22 / 5,474-480$.

YUAN, F., MA, L., XU, D.C., WEN, X.G. \& LIU, Y.Z. (2017): Sequential indicator simulation method in the application of the coal seam roof lithology prediction.Progress in Geophysics, 32/5, 2126-2131. doi: 10.6038 /pg20170537

ZHANG, Z.B., WANG, D. \& DING, J.X. (1981): Environmental changes since 13000 years ago in Beijing region.- Geological Sciences, 3, 259-268.

ZHAO, S.J., CHENG, J., YIN, G.M. \& ZAN, L.H. (2008): Palynological assemblages and palaeoclimatic significance in Beijing plain area since the Middle Pleistocene.Journal of Palaeogeography, 110/16, 637-646.

ZHAO, S.X. \& LIU, Y.J. (2007): 3D Visualizing of active fault surveying data.- Seismology and Geology, 29/4, 787-795.

ZHAO, X.T., SUN, X.P. \& ZHANG, Y.L. (1984): The palaeogeographic evolution since 30000 years ago in Beijing plain.- China Science, 6, 544-554.

ZHOU, K.S., YAN, F.H. \& LIANG, X.L. (1987): Pollen analysis of late quaternary in Beijing plain and significance.- Geological Science, 1, 57-64.

ZHOU, L.M. (2017): Application of Geostatistics Inversion in the Sandstone Reservoir Characterization of Delta Riverway.-Chenmical Intermediate, 1, 43-44.

ZHU, L.F., SUN, J.Z. \& ZHANG, C.J. (2012): Construction method of three-dimensional solid models for sedimentary stratigraphic systems.- Rock and Soil Mechanics, 33/11, 3243-3250. doi: 10.16285/j.rsm.2012.11.007. 